\title{
Point-of-care manufacturing: a single university hospital's initial experience
}

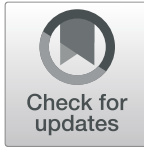

\author{
Jose Antonio Calvo-Haro ${ }^{1,2,3^{*}}$ (D), Javier Pascau ${ }^{3,4}$, José Manuel Asencio-Pascual ${ }^{1,2,3}$, Felipe Calvo-Manuel ${ }^{5}$, \\ Maria José Cancho-Gil 1,3, Juan Francisco Del Cañizo López 1,2,3, María Fanjul-Gómez ${ }^{1,3}$, Roberto García-Leal ${ }^{1,2,3}$, \\ Guillermo González-Casaurrán 1,3, Manuel González-Leyte ${ }^{1,3}$, Juan Antonio León-Luis 1,2,3, Lydia Mediavilla-Santos ${ }^{1,3}$, \\ Santiago Ochandiano-Caicoya 1,3, Ramón Pérez-Caballero 1,3, Almudena Ribed-Sánchez ${ }^{1,3}$, Javier Río-Gómez ${ }^{1,3}$, \\ Eduardo Sánchez-Pérez ${ }^{1,3}$, Javier Serrano-Andreu ${ }^{5}$, Manuel Tousidonis-Rial ${ }^{1,3}$, Javier Vaquero-Martín 1,2,3, \\ Sonia García San José ${ }^{1,3}$ and Rubén Perez-Mañanes ${ }^{1,2,3}$
}

\begin{abstract}
Background: The integration of 3D printing technology in hospitals is evolving toward production models such as point-of-care manufacturing. This study aims to present the results of the integration of 3D printing technology in a manufacturing university hospital.

Methods: Observational, descriptive, retrospective, and monocentric study of 907 instances of 3D printing from November 2015 to March 2020. Variables such as product type, utility, time, or manufacturing materials were analyzed.

Results: Orthopedic Surgery and Traumatology, Oral and Maxillofacial Surgery, and Gynecology and Obstetrics are the medical specialties that have manufactured the largest number of processes. Working and printing time, as well as the amount of printing material, is different for different types of products and input data. The most common printing material was polylactic acid, although biocompatible resin was introduced to produce surgical guides. In addition, the hospital has worked on the co-design of custom-made implants with manufacturing companies and has also participated in tissue bio-printing projects.
\end{abstract}

Conclusions: The integration of 3D printing in a university hospital allows identifying the conceptual evolution to "point-of-care manufacturing."

Keywords: 3D printing, Manufacturing university hospital, POC manufacturing, Preoperative planning, Biomodel, Surgical guides, Custom implants

\section{Background}

$3 \mathrm{D}$ printing is a disruptive technology and represents a paradigm shift in healthcare delivery [1]. The term "3D Printing" refers to the transformation of a digital model into a tangible three-dimensional object, with examples

\footnotetext{
* Correspondence: calvoharo@yahoo.es

${ }^{1}$ Advanced Planning and 3D Manufacturing Unit, Hospital General Universitario Gregorio Marañón, Calle Doctor Esquerdo, 46, 28007 Madrid, Spain

${ }^{2}$ Faculty of Medicine, Universidad Complutense, Madrid, Spain

Full list of author information is available at the end of the article
}

including anatomical models (biomodels) [2, 3], medical devices [4], surgical instruments $[5,6]$, custom-made implants [7-10], drugs [11-13], or even organs and tissues [14-16]. 3D printing enables patient-specific precision medicine with improved medical communication, and reports in the literature present shorter medical procedures, personalized medical devices, or simulation for medical training $[17,18]$.

Greater accessibility to 3D printing software and hardware technologies has enabled hospital-based 3D printing, showing how lead times and costs can be reduced 
[19]. Hospital 3D printing labs generate value in personalized medicine by assembling a professional team and the necessary resources [20-22]. With the proper quality and safety infrastructure, hospital-based 3D printed products can be affordable and incorporate a hub-andspoke model, where more complex manufacturing university hospitals are identified as "hubs," and smaller, less diverse labs serve as the "spokes." This approach enables each institution to adjust resources accordingly, objectively identifying each partners' strengths and limitations. The result is the creation of strong 3D printing alliances [20, 23].

3D printing within a hospital is a paradigm shift, moving away from traditional industry-based manufacturing limitations to propose custom implants [24-27] or bioprinting [28-30]. These hospital-based labs have been referred to as point-of-care (POC) manufacturing and require pecuniary responsibility, technical competence, updated physical resources, and engaged human resources [20].

Hospital General Universitario Gregorio Marañón has been developing the POC 3D-printing model since 2015. This study aims to present the experience from this integration of 3D printing technology in our hospital. Our results show how POC manufacturing workflow is a paradigm of personalized medicine in all steps, from clinical indication and surgical planning to the design and manufacturing of patient-specific solutions.

\section{Methods}

We present an observational, descriptive, retrospective, and monocentric study of 3D printing experience in the Advanced Planning and Manufacturing 3D Unit (UPAM3D) at Hospital General Universitario Gregorio Marañón (Madrid, Spain). We include all production recorded from the first 3D-printed case in November 2015 to March 2020, when the activity at UPAM3D was temporarily interrupted due to the COVID-19 pandemic.

3D printing transforms a digital model into a real and tangible three-dimensional product. Digital 3D models can be obtained from different sources: digital radiological studies, three-dimensional scanning, computational design (CAD), or reverse engineering. The products are built layer by layer from the digital model using different technologies and materials depending on the final application $[31,32]$.

In this study, we have defined the following variables to analyze the 3D printing activity at UPAM3D:

- Required product: Describes the type of product that is requested by the original user. It can be an anatomical model, a surgical guide/instrument for an interventional procedure, or a surgical navigation tool.
- Product utility: It defines the primary function of the product. Although these products have great value as a communication tool in most cases, it has been described as such only when communication was the essential value of the product. Other alternatives are teaching, instrumental, research, preoperative planning, intraoperative utility, and others.

- Input data: Describes the original data provided by the requesting user. Possible values are DICOM files [DICOM], 3D digital model design [3D model], or other materials. This last case could be a drawing or an existing tool with design improvement suggestions, which would be reverse-engineered to obtain a 3D model.

- Work time: Time allocated by the medical and technical team in all steps required to complete the project and obtain a final delivery product. This included 3D model design, 3D printing preparation (slicing), and post-processing of the 3D-printed result after manufacturing.

- 3D printing time: Time required by the 3D printer to manufacture the product.

- Quantity of 3D printing material: Weight of the material (in grams) used by the printer for each product.

- Type of 3D printing material: Type of material used to manufacture the product that depends on the 3D printing technology. Two types of technology were available during this study: fused deposition modeling (FDM), which prints fusing different compositions of plastic materials, and vat photopolymerization (SLA technology), a process in which a liquid photopolymer (resin) is converted into solid material when illuminated by a laser.

Quantitative variables are described as mean and median values, while qualitative variables are presented as numbers and percentages.

\section{Results}

Figure 1 summarizes the activity of the different departments for a total of 907 models 3D printed during the study. The detailed data is shown in Table 2. Most of them were clinical departments, being the most active Orthopedic Surgery and Traumatology, Maxillofacial Surgery, and Gynecology and Obstetrics with 52.81\%, $6.93 \%$, and $5.06 \%$ of the processes, respectively. Apart from the clinical activity, the Hospital Research Institute, and UPAM3D demanded several research products.

The products requested were anatomical models in $87.02 \%$ of cases and surgical guides in $11.66 \%$. The remaining cases $(1.32 \%)$ were patient-specific instruments for surgical procedures in which 3D printing was integrated with navigation or augmented reality, 


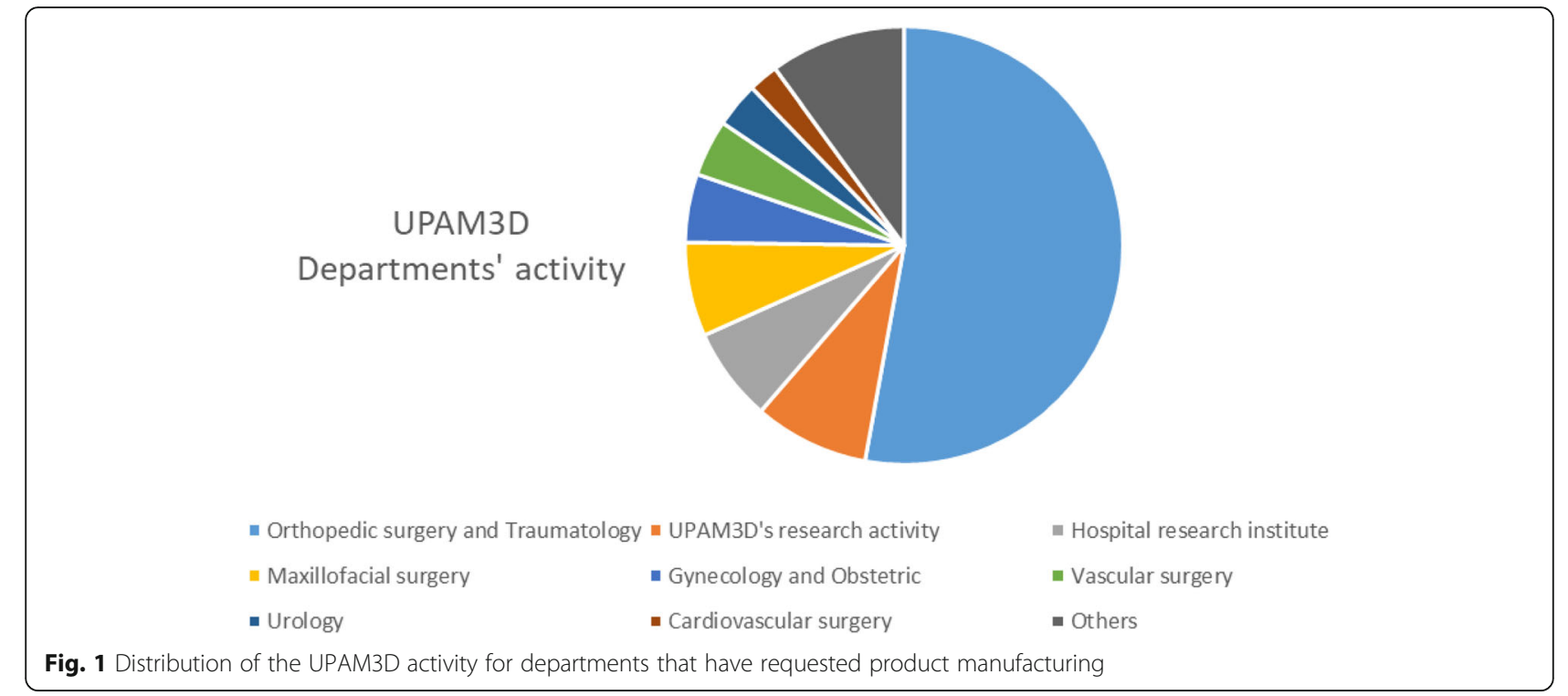

providing added value, as in the example displayed in Fig. $2[33,34]$.

The utility has been different depending on the type of product manufactured. Anatomical models were primarily manufactured for preoperative planning (38.61\%), communication $(9.35 \%)$, or research $(18.26 \%)$. On the other side, surgical guides or instruments have mainly been used intraoperatively (Table 1).

When we analyze the type of products requested by each department (Table 2), we can observe that anatomical models are the most common. However, the profile for some surgical departments is different. For instance, Pediatric Surgery requested positioning guides in $70 \%$ of the cases.

Table 2 details the distribution of input data provided to perform the 3D printing process, with DICOM images, 3D models, and other materials in $47.74 \%$, $43.67 \%$, and $8.58 \%$ of the cases. Figure 3 shows an example of a 3D-printed camera attachment for a surgical lamp belonging to this last category. When analyzing each department's input data, we can observe that the Neurosurgery provided DICOM images in all their requests. At the same time, other departments were able to prepare a 3D model for their products. Orthopedic Surgery and Traumatology is a good example: their input data was a 3D model in $31 \%$ and $67.16 \%$ of their anatomical models and surgical guides, respectively.

Table 3 shows the technical details of the 3D printing projects during the study period. The total working hours were 8896, with an average of $9.79 \mathrm{~h}$ (median $3 \mathrm{~h}$ ) per process. The total running time for all $3 \mathrm{D}$ printers was 10,271 h, with an average of $11.29 \mathrm{~h}$ (median $6 \mathrm{~h}$ ) per process. However, working time and $3 \mathrm{D}$ printing time were different depending on the type of product
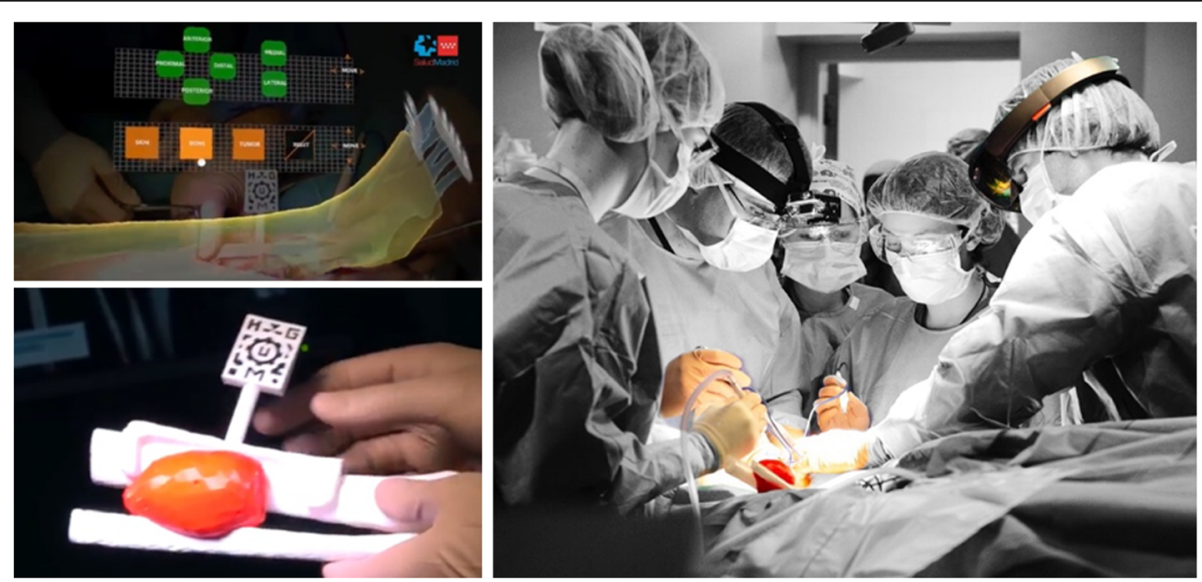

Fig. 2 Surgical procedure: combining augmented reality and 3D printing. Ewing tumor. Location, right leg. Date, 2018 
Table 1 Distribution of required products for each product utility

\begin{tabular}{|c|c|c|c|c|c|c|c|c|}
\hline & \multicolumn{8}{|l|}{ Product utility } \\
\hline & Communication & Teaching & Instrumental & Research & $\begin{array}{l}\text { Intraoperative } \\
\text { utility }\end{array}$ & $\begin{array}{l}\text { Preoperative } \\
\text { planning }\end{array}$ & Others & $\begin{array}{l}\text { Total } \\
(\%)\end{array}$ \\
\hline \multicolumn{9}{|l|}{ Required product } \\
\hline $\begin{array}{l}\text { Surgical guide/interventional } \\
\text { procedure }\end{array}$ & 0.11 & & & 0.11 & 11.44 & & & 11.66 \\
\hline Anatomical model & 9.35 & 12.54 & 0.55 & 18.26 & 0.66 & 38.61 & 7.04 & 87.02 \\
\hline Navigation tool & & & & 0.77 & 0.44 & 0.11 & & 1.32 \\
\hline Total (\%) & 9.46 & 12.54 & 0.55 & 19.14 & 12.54 & 38.72 & 7.04 & 100.00 \\
\hline
\end{tabular}

Table 2 Distribution of products and input data by departments

\begin{tabular}{|c|c|c|c|c|c|c|c|c|c|c|c|c|}
\hline & \multicolumn{4}{|c|}{$\begin{array}{l}\text { Surgical guide/interventional } \\
\text { procedure }\end{array}$} & \multicolumn{4}{|c|}{ Anatomical model } & \multicolumn{3}{|c|}{ Navigation } & \multirow[t]{2}{*}{$\begin{array}{l}\text { Total } \\
(\%)\end{array}$} \\
\hline & $\begin{array}{l}\mathrm{D} \\
\text { model }\end{array}$ & DICOM & Other & Total & $\begin{array}{l}3 \mathrm{D} \\
\text { model }\end{array}$ & DICOM & Other & Total & $\begin{array}{l}\mathrm{D} \\
\text { model }\end{array}$ & DICOM & Total & \\
\hline Anesthesiology & & & & & 0.99 & & 0.22 & 1.21 & & & & 1.21 \\
\hline Vascular surgery & 0.11 & 0.11 & & 0.22 & 1.32 & 2.53 & 0.11 & 3.96 & & & & 4.18 \\
\hline Biochemistry & & & & & 0.44 & & & 0.44 & & & & 0.44 \\
\hline Cardiology & & & & & 0.44 & 0.11 & & 0.55 & & & & 0.55 \\
\hline Cardiovascular surgery & & & & & 1.43 & 0.11 & 0.66 & 2.20 & & & & 2.20 \\
\hline General surgery & & & & & 0.44 & 0.11 & 0.11 & 0.66 & & 0.11 & 0.11 & 0.77 \\
\hline Maxillofacial surgery & 0.44 & 1.43 & & 1.87 & 1.43 & 3.19 & 0.44 & 5.06 & & & & 6.93 \\
\hline $\begin{array}{l}\text { Orthopedic surgery and } \\
\text { traumatology }\end{array}$ & 4.95 & 1.98 & 0.44 & 7.37 & 13.97 & 28.93 & 2.09 & 44.99 & 0.33 & 0.11 & 0.44 & 52.81 \\
\hline Pediatric surgery & 0.11 & 0.66 & & 0.77 & & 0.33 & & 0.33 & & & & 1.10 \\
\hline Plastic surgery & & & & & 0.22 & 0.33 & 0.11 & 0.66 & & & & 0.66 \\
\hline Thoracic surgery & & & & & 0.22 & 1.21 & & 1.43 & & & & 1.43 \\
\hline Hospital pharmacy & & & & & & & 0.22 & 0.22 & & & & 0.22 \\
\hline Gynecology and obstetric & & & & & 4.29 & 0.77 & & 5.06 & & & & 5.06 \\
\hline Hospital research institute & & & & & 4.07 & 0.11 & 1.98 & 6.16 & 0.77 & & 0.77 & 6.93 \\
\hline $\begin{array}{l}\text { Physical medicine and } \\
\text { rehabilitation }\end{array}$ & & & & & 0.11 & 0.11 & & 0.22 & & & & 0.22 \\
\hline Neonatology & & & & & & 0.22 & & 0.22 & & & & 0.22 \\
\hline Neurosurgery & & & & & & 1.43 & & 1.43 & & & & 1.43 \\
\hline Radiotherapy oncology & & & & & 0.22 & 0.11 & & 0.33 & & & & 0.33 \\
\hline Otorhinolaryngology & & & & & 0.11 & & & 0.11 & & & & 0.11 \\
\hline Radiology & & & & & 0.33 & 0.55 & 0.11 & 0.99 & & & & 0.99 \\
\hline Radiophysic & & & & & & & 0.11 & 0.11 & & & & 0.11 \\
\hline UPAM3D's research activity & & & & & 6.16 & 0.55 & 1.76 & 8.47 & & & & 8.47 \\
\hline Urology & & 1.43 & & 1.43 & 0.66 & 1.21 & & 1.87 & & & & 3.30 \\
\hline Other departments & & & & & 0.11 & & 0.22 & 0.33 & & & & 0.33 \\
\hline Total (\%) & 5.61 & 5.61 & 0.44 & 11.66 & 36.96 & 41.91 & 8.14 & 87.02 & 1.10 & 0.22 & 1.32 & 100.00 \\
\hline
\end{tabular}




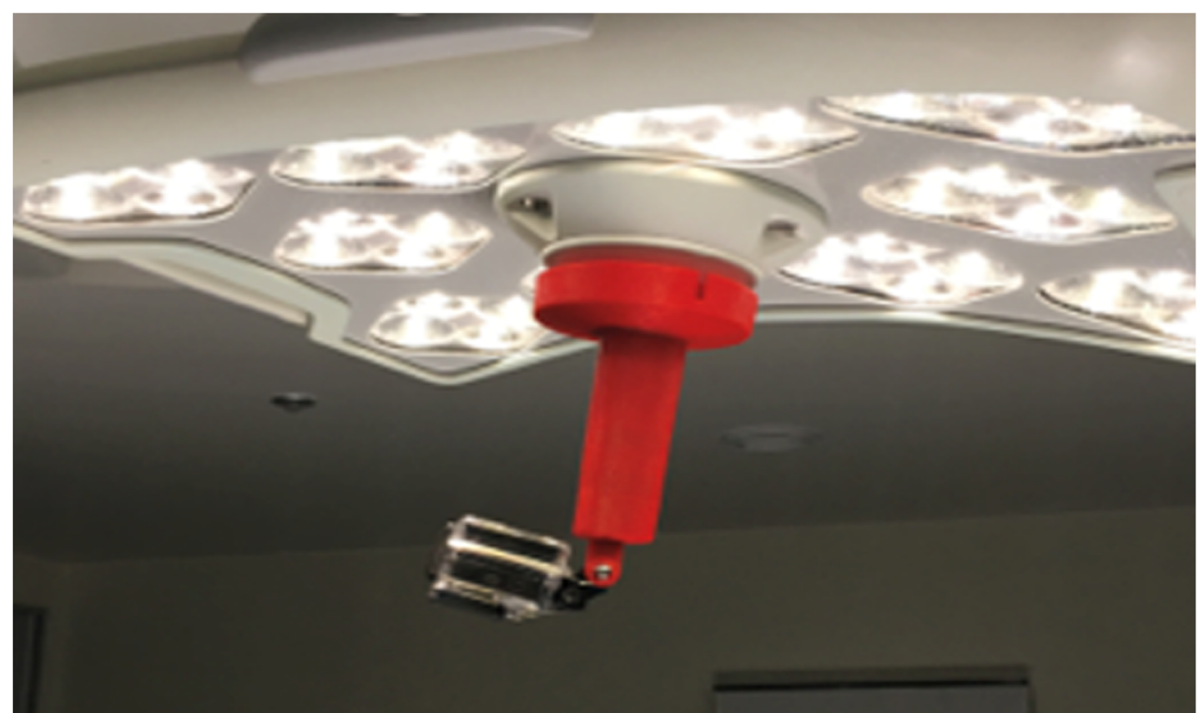

Fig. 3 Reverse engineering. Sterilizable surgical light handle with camera attachment. Date, 2016

and the input data. The production time for a product must consider both the working time of the staff involved in the design and printing processes (medical and technical team) and the manufacturing time required by the 3D printer.

The annual distribution of working and printing hours (Fig. 4) shows two lines that cross during the study period, due to a more significant number of working hours in the first years with increased printing times in recent years. This behavior can be explained by the increase in the complexity of the products being printed, combined with a reduction of the segmentation and image processing times required to obtain virtual 3D models from input data.

Total 3D printing material consumed was $100,587 \mathrm{~g}$, with an average of $110.65 \mathrm{~g}$ (median of $64 \mathrm{~g}$ ) per process (Table 3). 3D printers with FDM technology have been the most used, accounting for $94.65 \%$ of $3 \mathrm{D}$ printing material, being polylactic acid (PLA) the most widely used (79.30\%). This is a rigid material replicating bone structures with remarkable realism. Many other materials have been tested in specific projects, some of them flexible such as thermoplastic polyurethane (TPU) or Filaflex (thermoplastic elastomer based on polyurethane and certain additives). They allow replicating vascular structures, solid organs, or muscular-tendon structures. Supporting materials, such as polyvinyl alcohol (PVA), facilitate post-processing, and improve printing quality. The contribution of PVA is depicted in Fig. 5, showing a phantom with internal cavities that could be manufactured with rigid supports. The recent introduction of SLA resins, biocompatible, and certified for medical use, allowed us to respond to an increased demand for positioning guides or patient-specific instruments. In total,

Table 3 Technical details of the 3D printing projects

\begin{tabular}{|c|c|c|c|c|c|c|c|c|c|c|c|c|}
\hline & \multicolumn{4}{|c|}{ Surgical guide/interventional procedure } & \multicolumn{4}{|c|}{ Anatomical model } & \multicolumn{3}{|l|}{ Navigation } & \multirow[t]{2}{*}{ Total } \\
\hline & 3D model & DICOM & Other & Total & 3D model & DICOM & Other & Total & 3D model & DICOM & Total & \\
\hline \multicolumn{13}{|c|}{ Work time (hours) } \\
\hline Mean & 13.39 & 3.21 & 6.75 & 8.24 & 1.85 & 5.73 & 10.59 & 10.07 & 1 & 30.5 & 5.91 & 9.79 \\
\hline Median & 10 & 2 & 1 & 4 & 3 & 2 & 3.5 & 2 & 10 & 1.5 & 6 & 3 \\
\hline \multicolumn{13}{|c|}{ 3D printing time (hours) } \\
\hline Mean & 2.96 & 7.78 & 14.75 & 5.72 & 8.07 & 16.78 & 6.23 & 12.08 & 4.9 & 25 & 8.25 & 11.29 \\
\hline Median & 2 & 4 & 6.5 & 2 & 4.5 & 12 & 2 & 7 & 7 & 2 & 5 & 6 \\
\hline \multicolumn{13}{|c|}{ Quantity 3D printing material (grams) } \\
\hline Mean & 41.74 & 74.96 & 193 & 63.41 & 90.64 & 149.53 & 73.4 & 117.31 & 63.6 & 157.5 & 79.25 & 110.65 \\
\hline Median & 30 & 72 & 61 & 42.5 & 51 & 97 & 29.5 & 66 & 83.5 & 25.5 & 81 & 64 \\
\hline
\end{tabular}




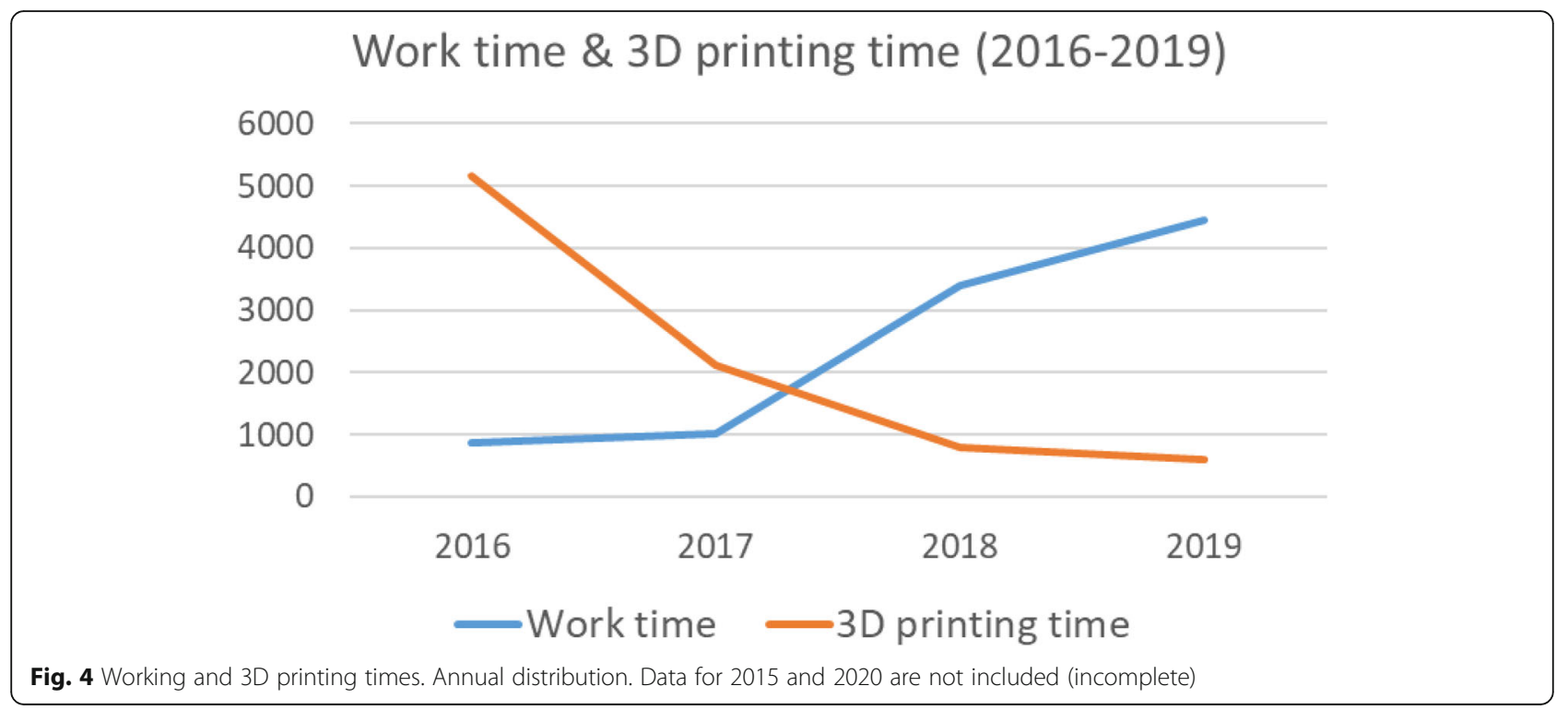

4.95\% of products have been printed with biocompatible resins (Dental SG Resin and Dental LT Clear Resin, Formlabs), representing $5.35 \%$ of the consumed material. Figure 6 shows several projects printed in biocompatible SLA resins.

Our experience as a manufacturing university hospital has increased our capacity to work with different commercial companies in the sector, participating in the codesign of personalized implants [35] (Fig. 7) or collaborating with external research groups in bioprinting [36, 37] (Fig. 8).

\section{Discussion}

3D printing addresses the growing complexities in healthcare and enables a more sustainable future as a scalable and cost-effective technology. It is a patientspecific process (Fig. 9) that increases the efficiency in different steps of the treatment workflow, bringing higher level of customization and predictability, as proposed by the GIRFT methodology (Getting It Right First Time) [19, 38-42].

Hospital General Universitario Gregorio Marañón has pioneered the transversal implementation of hospital 3D printing with an "in-house" medical 3D printing laboratory integrated into the clinical workflow of more than 20 medical-surgical specialties. The hospital has obtained authorization from the local government to manufacture medical devices, in compliance with the international standard ISO 13485 for quality management systems for medical products [43-48]. During the first 2 years, UPAM3D activity focused on identifying and optimizing specific software and hardware, materials, and manufacturing parameters. This profile is reflected in the results, showing higher involvement of the research departments and a large number of working hours. The expertise
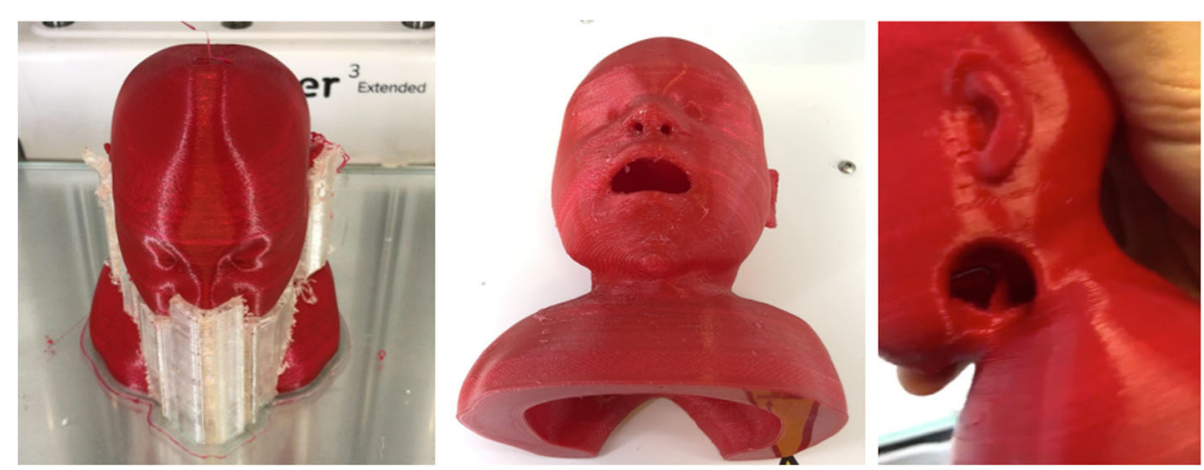

Fig. 5 3D printing materials (TPU, PVA). Pediatric intubation training. Date, 2018 

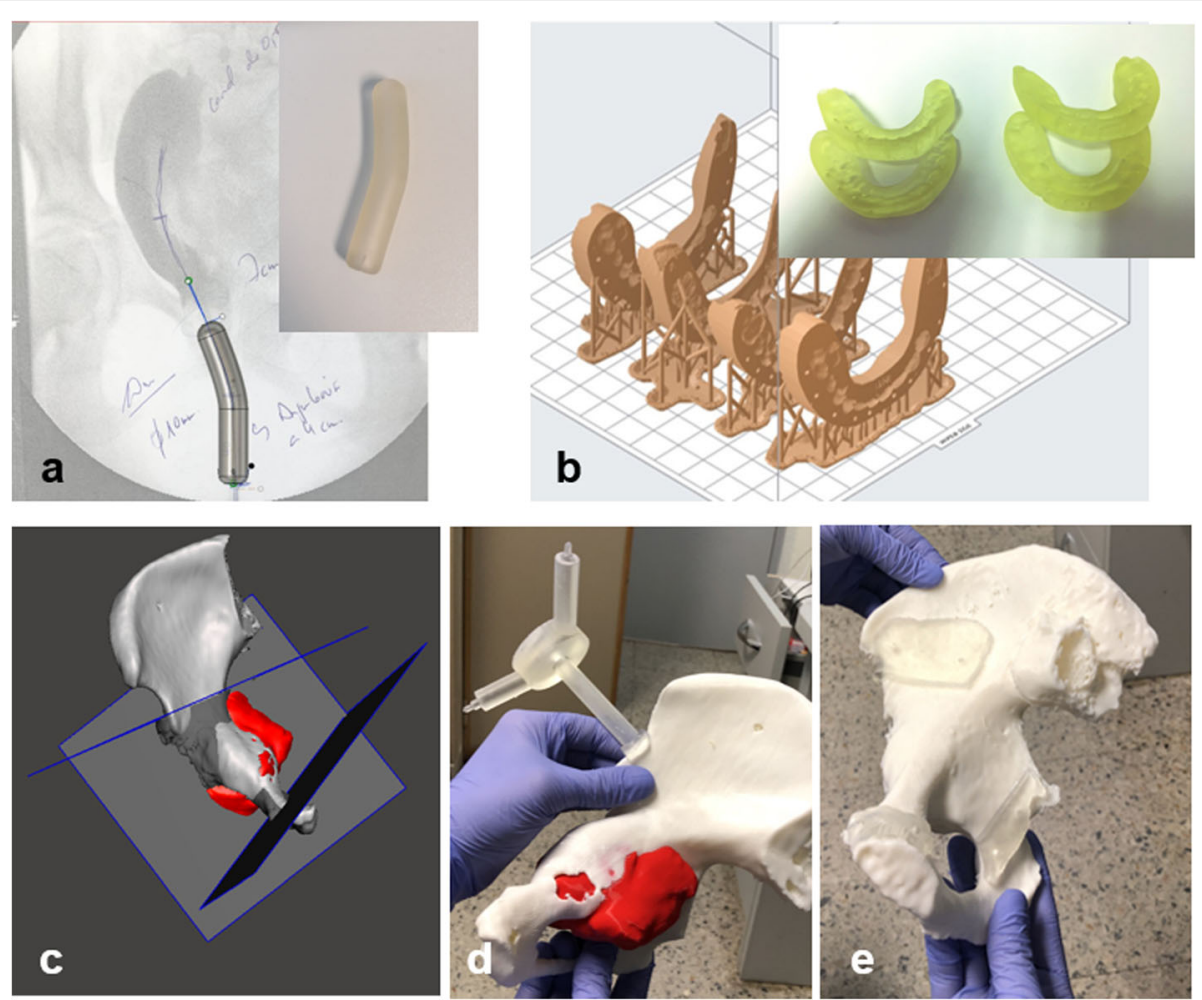

Fig. 6 3D printing materials (biocompatible resin). Surgical guides. Clinical applications: urogenital malformation surgery (a), orthognathic surgery (b), orthopedic oncology (c-e)
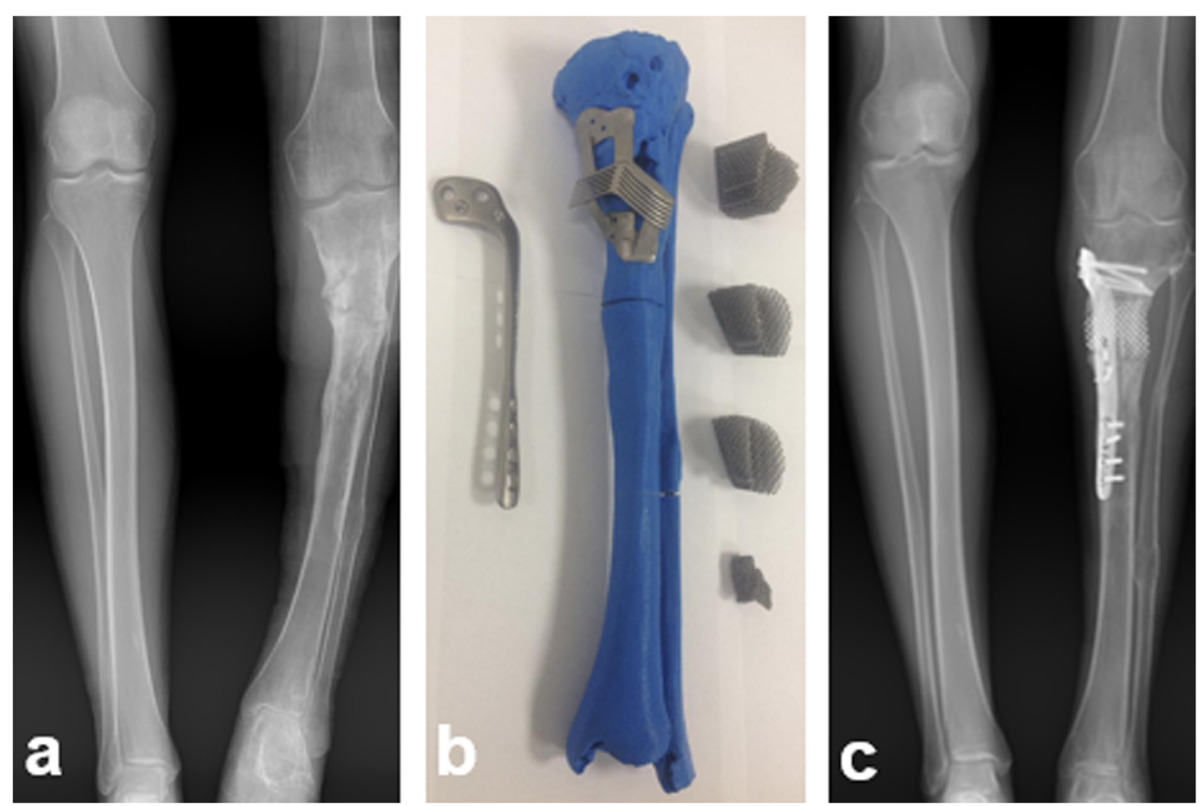

Fig. 7 Customized implant. Preoperative X-ray of a tibial deformity (a). Anatomical model and customized implants (b). Post-operative X-ray (c) Date, 2017 


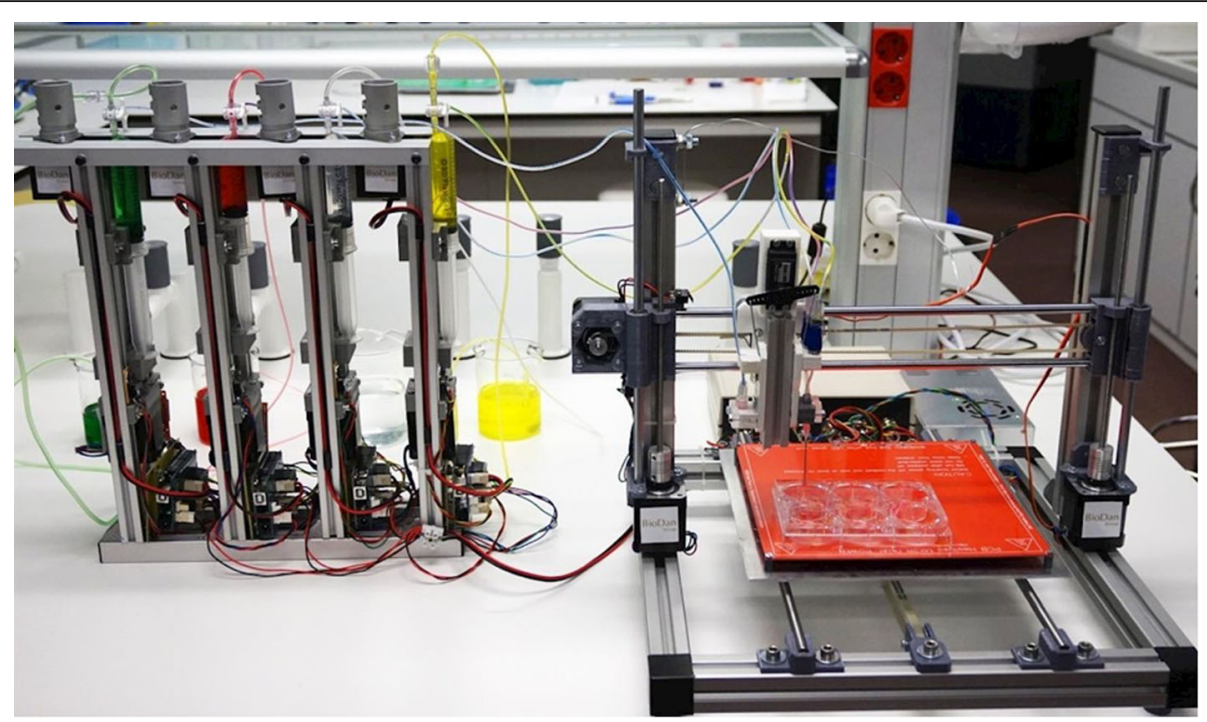

Fig. 8 Human skin bioprinting. Date, 2016

acquired during this initial phase resulted in a decrease in working hours every year, and the inclusion of new requesting users from clinical departments.

It is important to identify the clinical areas gaining the most benefits from integrating 3D printing in their clinical workflow. The Radiological Society of North America 3D printing group (3D Special Interest Group RSNA) states that musculoskeletal, craniofacial, vascular, or congenital heart defects are the specialties in which it is most efficient to use anatomical models [49]. Our results show that Orthopedic Surgery and Traumatology, Maxillofacial Surgery, Gynecology and Obstetrics, and Vascular Surgery accounted for $68.98 \%$ of the total activity. Research activity (UPAM3D or the Research Institute) reported $15.4 \%$, and the remaining $15.62 \%$ (142 cases) included other clinical departments. Our role as a manufacturing university hospital has allowed adaptation and optimization of response times. This is important in
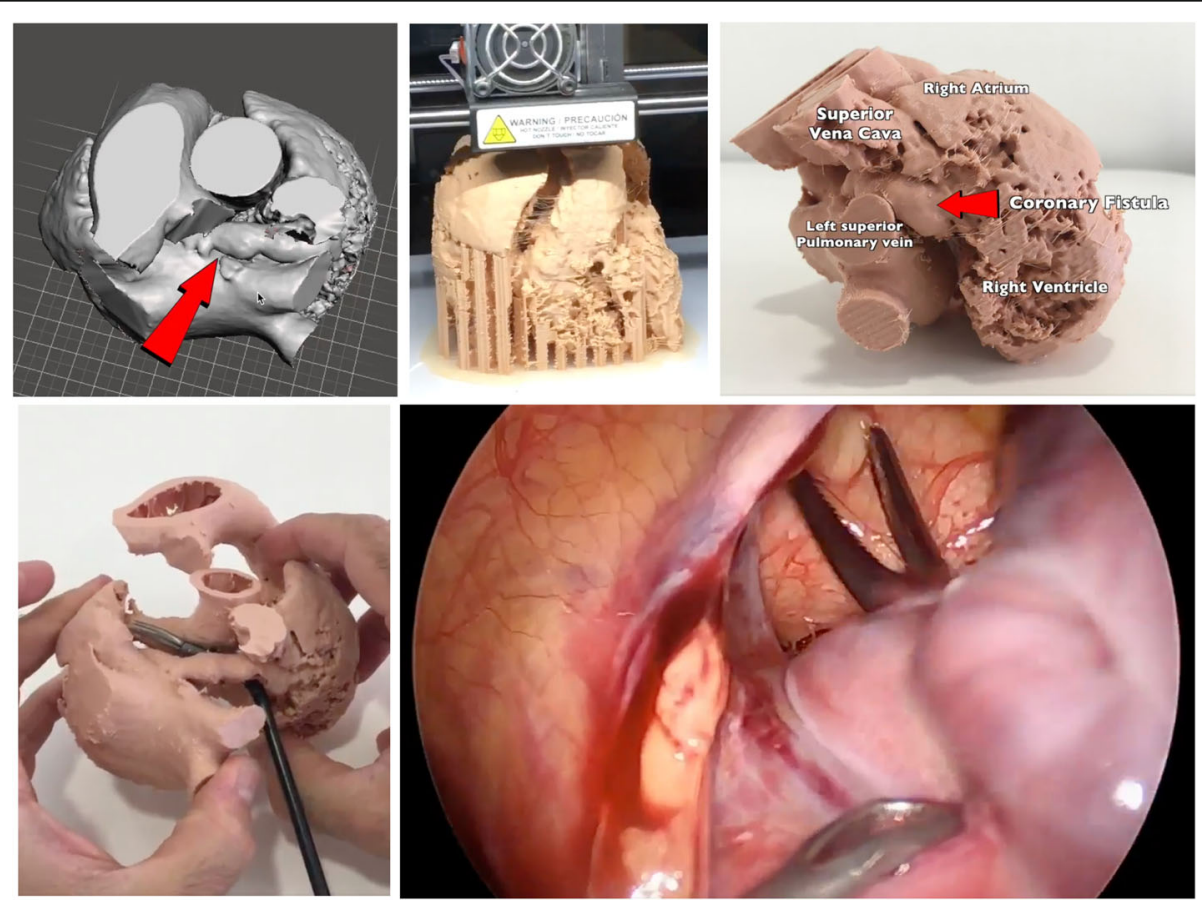

Fig. 9 Preoperative planning. Congenital heart defect. Date, 2017 


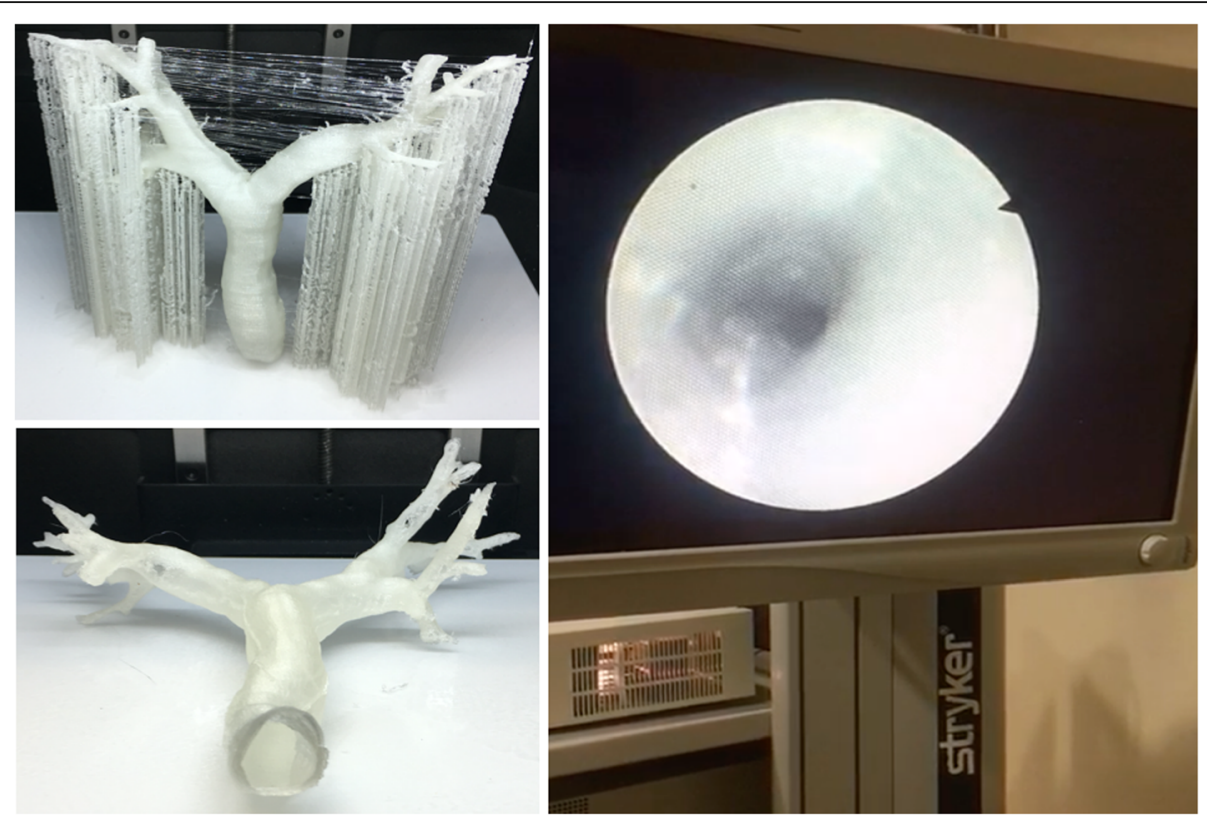

Fig. 10 Airway simulator. Date, 2017

surgical specialties such as Traumatology [50] or Vascular Surgery [51], where traditional manufacturing presents restrictions in lead times, process outsourcing, or associated costs.

The use of anatomical models for preoperative planning is an interesting utility in all surgical specialties [49]. Anatomical models are replicas of a patient-specific organ or anatomical region manufactured in different materials with millimetric accuracy. They are used as a communication tool with patients or between professionals [3], facilitate decision-making, and allow simulation before the surgical procedure [2]. These simulators of medical techniques such as orotracheal intubations [52], sutures [53], endoscopies [54], endovascular
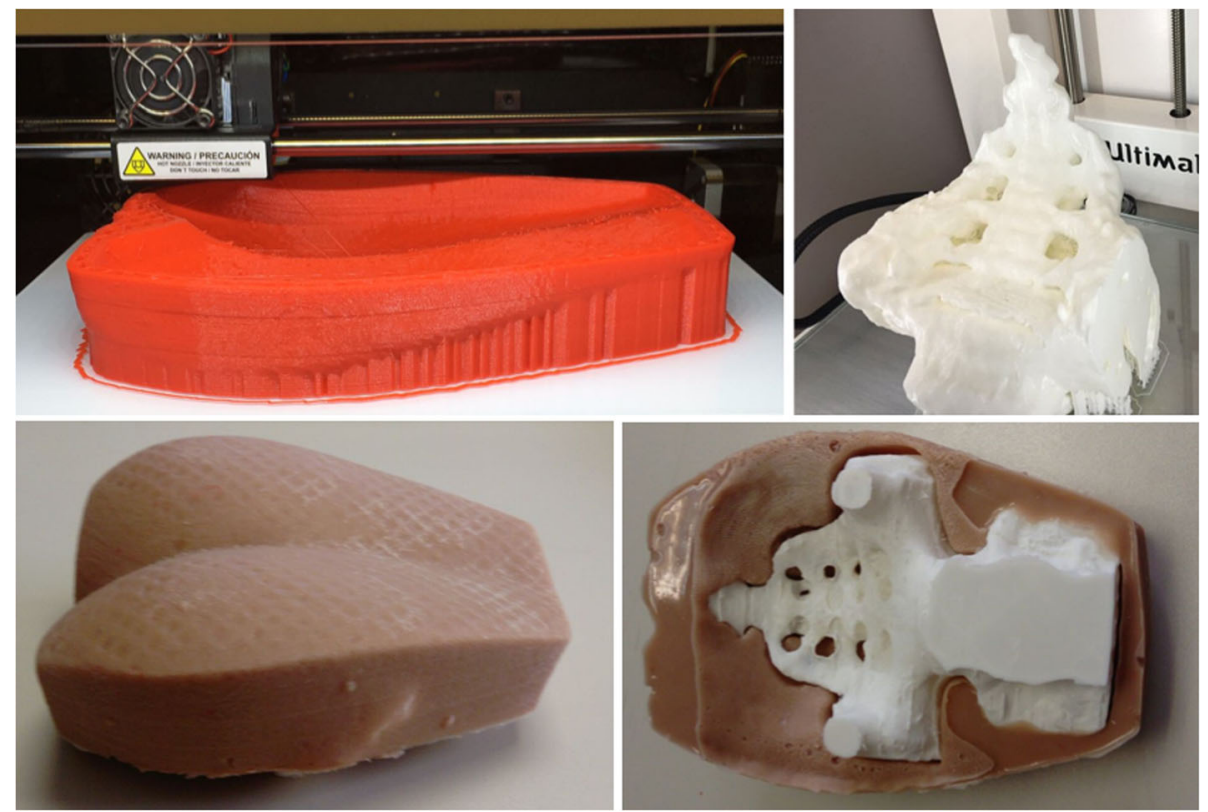

Fig. 11 Simulation of interventional procedures. Sacral root neuro stimulation. Date, 2016 

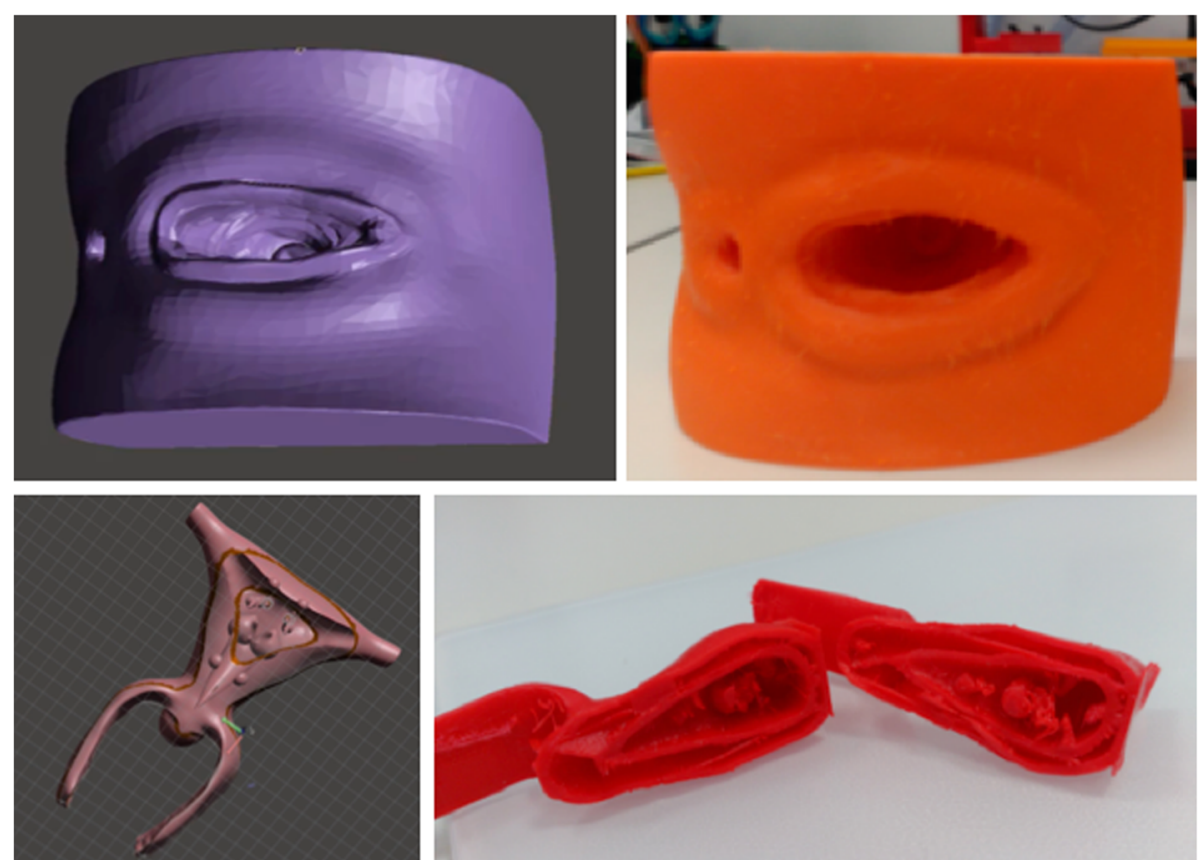

Fig. 12 Simulators for gynecological training. Date, 2016

interventions [55], or other surgical procedures [56-58] can be developed at a very low cost. They can also be an alternative to corpses for teaching anatomy [59-61].

In this study, $86.80 \%$ of the required products were anatomical models, useful not only in surgical planning but also as a communication or research tool. In the same way that a university hospital complements university education enriching the academic environment, a manufacturing university hospital does not replace factories. In this setting, 3D printing goes hand-in-hand with translational research and teaching, acting as an accelerator for clinical innovation. Figures 10, 11, 12, and 13 show
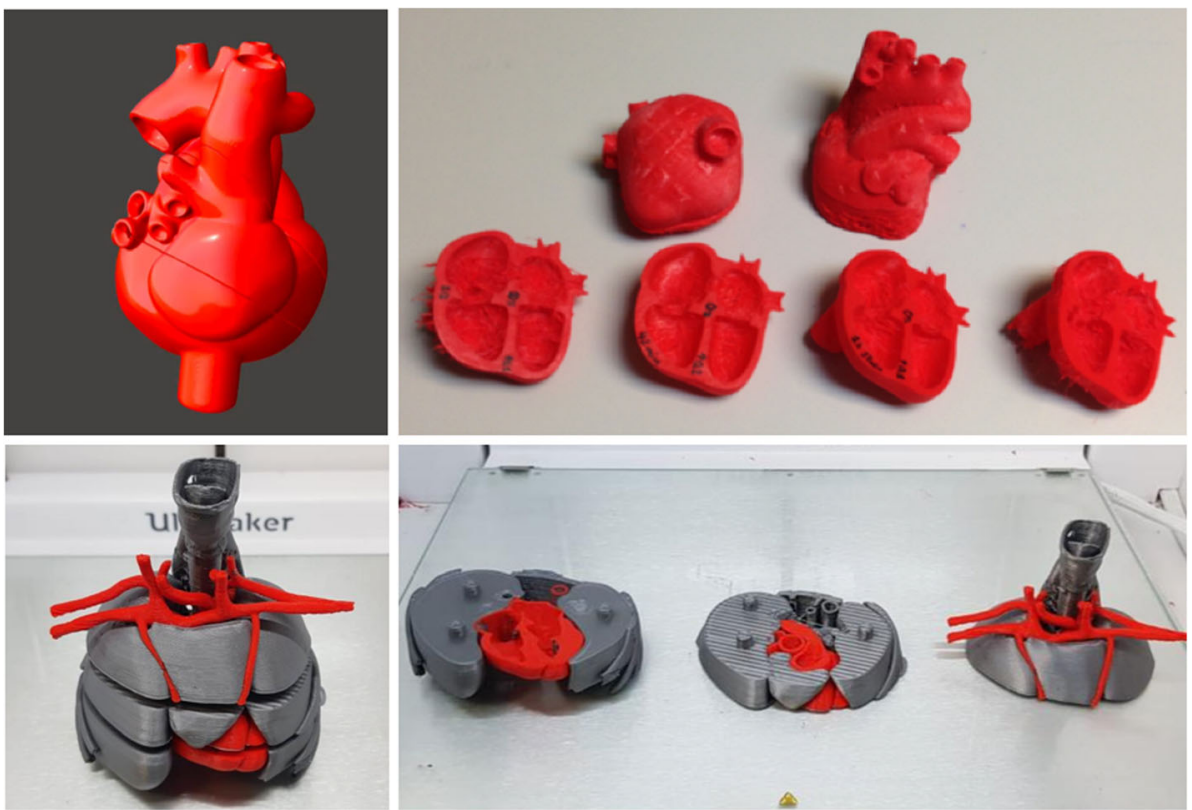

Fig. 13 Anatomical models for teaching. Fetal cardiology. Date, 2019 

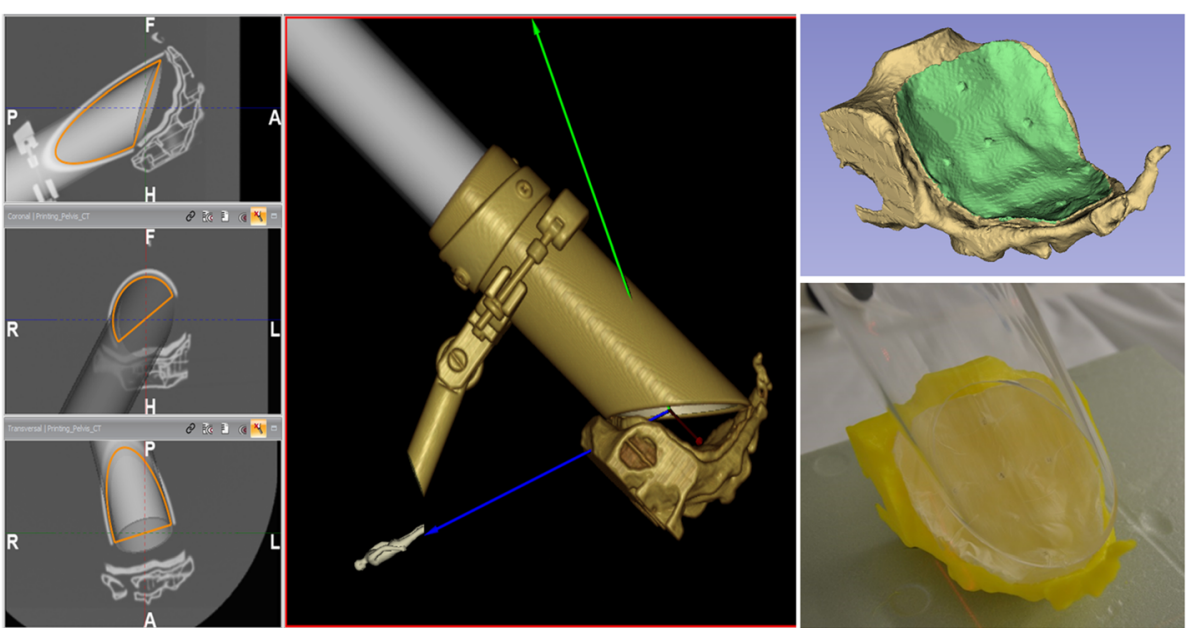

Fig. 14 Sacral tumor. Radiotherapy treatment simulation. Dose measurement. Date, 2017

examples of this approach for medical training. Our "inhouse" 3D printing approach has allowed complete control and monitoring of the process, from the indication to the manufacture of a customized medical-surgical solution. It also presents added value when manufacturing guides, instruments, or customized implants [62-64]. As an example, Fig. 14 shows a complex co-design with radiation oncologists and physicists to evaluate intraoperative radiation therapy dose on patient-specific data.

The technical details in Table 3 show how the duration of the process depended on the type of product required and the input data received. It may seem that work time should be lower for an anatomical model than for a surgical guide, since the last requires a specific design. However, the average work time showed no significant differences between these two products in our study. This can be explained by the segmentation and image processing time required by anatomical models, which can be quite laborious for complex anatomical areas, as shown in Fig. 15. Anatomical models showed both long printing times and a large amount of material compared to surgical guides. We also observed an increase in 3D printing time in the last 2 years, justified by the complexity of 3D-printed products, which usually required the optimization of manufacturing parameters with different materials.

The availability of machines for "in-house" manufacturing by material extrusion and vat photopolymerization has allowed the production of anatomical models, surgical guides, and patient-specific instruments. A multidisciplinary team, with valuable experience and clinical knowledge, achieved low response times, maintaining the enrollment of most hospital departments in the POC manufacturing model. This approach is aligned with the current regulatory framework of this technology applied to personalized medicine, which identifies the
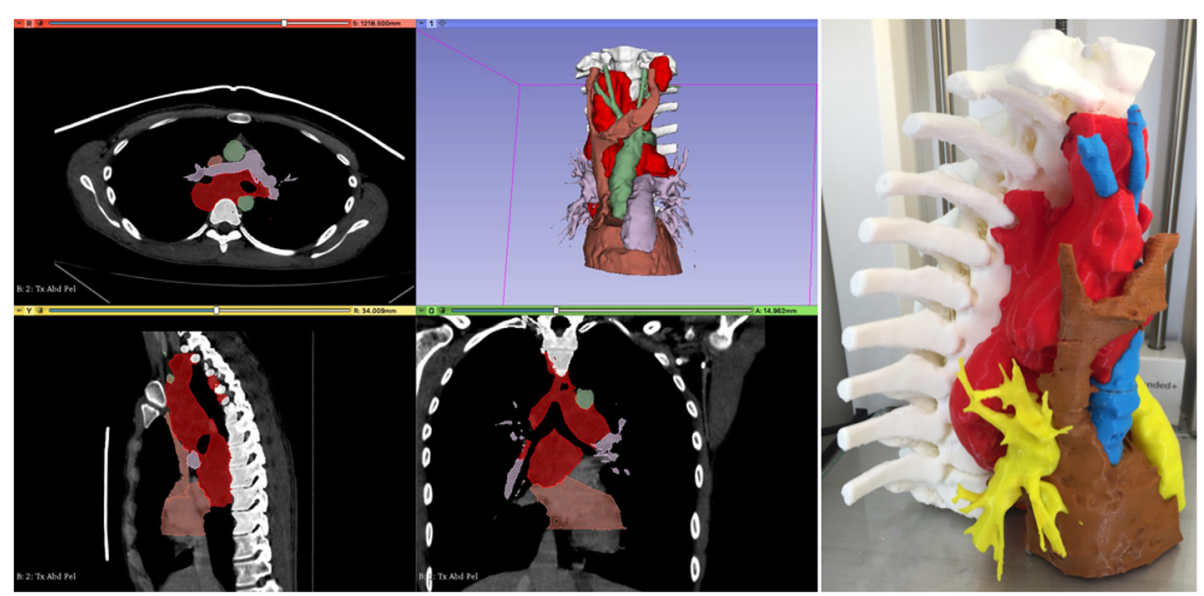

Fig. 15 Anatomical model of a complex anatomical area. Date, 2019 
prescribing physician as the final responsible for the process [65-68].

\section{Conclusions}

This study identifies the possibilities of integrating 3D printing technology in a hospital. This experience shows the conceptual evolution of the hospital's 3D printing workflow toward POC manufacturing. Our results are limited to a single center, so it is essential to propose multicenter studies and elaborate consensus documents to take advantage of the upcoming contributions of 3D printing in healthcare.

\section{Abbreviations \\ 3D: Three dimensional; 3DP: Three-dimensional printing; ABS: Acrylonitrile butadiene styrene; COVID-19: Coronavirus disease 2019; DICOM: Digital imaging and communication on medicine; FDM: Fused deposition modeling; GIRFT: Getting It Right First Time; ISO: International Organization for Standardization; PLA: Polylactic acid; POC: Point of care; POCM: Point-of-care manufacturing; PVA: Polyvinyl alcohol; SLA: Stereolithography; TPU: Thermoplastic Polyurethane; UPAM3D: Advanced Planning and 3D Manufacturing Unit}

\section{Acknowledgements}

We would like to thank the effort and dedication of the staff working in the Advanced Planning and 3D Manufacturing Unit of the center, with special mention to Diego Trapero, interns, and technical staff of Universidad Carlos III de Madrid. Thanks to all the Hospital 3D Printing Commission members for facilitating the development of the project, and especially to the health professionals for the outstanding professionalism and support shown. This study was partially supported by project PI18/01625 (Ministerio de Ciencia, Innovación y Universidades, Instituto de Salud Carlos III, and European Regional Development Fund "Una manera de hacer Europa").

\section{Authors' contributions}

Jose Antonio Calvo-Haro and Rubén Perez-Mañanes conceived the idea of the study; Jose Antonio Calvo-Haro, Javier Pascau, Lydia Mediavilla-Santos, Javier Vaquero-Martín, and Rubén Perez-Mañanes contributed to the study design; Santiago Ochandiano-Caicoya, Ramón Pérez-Caballero, Almudena Ribed-Sánchez, Javier Río-Gómez, Eduardo Sánchez-Pérez, Javier SerranoAndreu, and Manuel Tousidonis-Rial performed the statistical analysis; Jose Antonio Calvo-Haro, Javier Pascau, José Manuel Asencio-Pascual Felipe Calvo-Manuel, Maria José Cancho-Gil, Juan Francisco Del Cañizo López, María Fanjul-Gómez, Roberto García-Leal, Guillermo González-Casaurrán, Manuel González-Leyte, Juan Antonio León-Luis, Sonia García San José, and Rubén Perez-Mañanes took part in the interpretation of the results; and Jose Antonio Calvo-Haro, Javier Pascau, and Rubén Perez-Mañanes critically revised the manuscript drafts. All authors read and approved the final version of the manuscript.

\section{Funding}

Analysis and interpretation of the data supported by Project PI18/01625 (Ministerio de Ciencia, Innovación y Universidades, Instituto de Salud Carlos III) and European Regional Development Fund ("Una manera de hacer Europa").

\section{Availability of data and materials}

The authors declare that they have followed their center's protocols on the publication of patient data. All data analyzed during the current study are available from the corresponding author on reasonable request.

\section{Declarations}

\section{Ethics approval and consent to participate}

The authors state that no experiments on humans or animals have been conducted for this research. The authors declare that patient data do not appear in this article and that they are in possession of the patients' informed consent for participation in the study and publication of the results.

\section{Consent for publication}

The authors declare patients are in possession of the patients' informed consent for participation in the study and publication of the results.

\section{Competing interests}

The authors declare that they have no competing interests.

\section{Author details}

${ }^{1}$ Advanced Planning and 3D Manufacturing Unit, Hospital General Universitario Gregorio Marañón, Calle Doctor Esquerdo, 46, 28007 Madrid, Spain. ${ }^{2}$ Faculty of Medicine, Universidad Complutense, Madrid, Spain. ${ }^{3}$ Instituto de Investigación Sanitaria Gregorio Marañón, Madrid, Spain. ${ }^{4}$ Departamento de Bioingeniería e Ingeniería Aeroespacial, Universidad Carlos III de Madrid, Madrid, Spain. ${ }^{5}$ Clínica Universidad de Navarra, Madrid, Spain.

Received: 4 June 2020 Accepted: 8 April 2021

Published online: 22 April 2021

\section{References}

1. Michalski MH, Ross JS. The shape of things to come. JAMA. 2014;312(21): 2213-4. https://doi.org/10.1001/jama.2014.9542.

2. Zheng Y, Yu D, Zhao J, Wu Y, Zheng B. 3D printout models vs. 3D-rendered images: which is better for preoperative planning? J Surg Educ. 2016;73(3): 518-23. https://doi.org/10.1016/j.jsurg.2016.01.003.

3. Zheng B, Wang $X$, Zheng $Y$, Feng J. 3D-printed model improves clinical assessment of surgeons on anatomy. J Robot Surg. 2018;13(1):61-7. https:// doi.org/10.1007/s11701-018-0809-2.

4. Tack P, Victor J, Gemmel P, Annemans L. 3D-printing techniques in a medical setting: a systematic literature review. Biomed Eng Online. 2016; 15(1):115. https://doi.org/10.1186/s12938-016-0236-4

5. Yang H-S, Park J-Y. 3D printer application for endoscope-assisted spine surgery instrument development: from prototype instruments to patientspecific 3D models. Yonsei Med J. 2020;61(1):94-9. https://doi.org/10.3349/ ymj.2020.61.1.94.

6. Mayilvaganan S, Bothra S. 3D printed surgical instruments: the design and fabrication process. World J Surg. 2017;41(9):2414. https://doi.org/10.1007/ s00268-017-3946-2.

7. Choy WJ, Mobbs RJ. Current state of 3D-printed custom-made spinal implants. Lancet Digit Health. 2019;1(4):e149-50. https://doi.org/10.1016/s2 589-7500(19)30081-0.

8. Lee N. The Lancet Technology: 3D printing for instruments, models, and organs? Lancet. 2016;388(10052):1368. https://doi.org/10.1016/s0140-6736(1 6)31735-4.

9. Burnard JL, Parr WCH, Choy WJ, Walsh WR, Mobbs RJ. 3D-printed spine surgery implants: a systematic review of the efficacy and clinical safety profile of patient-specific and off-the-shelf devices. Eur Spine J. 2019;29(6): 1248-60. https://doi.org/10.1007/s00586-019-06236-2.

10. Ni J, Ling H, Zhang S, Wang Z, Peng Z, Benyshek C, et al. Three-dimensional printing of metals for biomedical applications. Mater Today Bio. 2019;3: 100024. https://doi.org/10.1016/j.mtbio.2019.100024.

11. Fitzgerald S. FDA approves first 3D-printed epilepsy drug experts assess the benefits and caveats. Neurol Today. 2015;15(18):26-7. https://doi.org/10.1 097/01.nt.0000472137.66046.b5.

12. Norman J, Madurawe RD, Moore CMV, Khan MA, Khairuzzaman A. A new chapter in pharmaceutical manufacturing: 3D-printed drug products. Adv Drug Deliv Rev. 2017;108:39-50. https://doi.org/10.1016/j.addr.2016.03.001.

13. Chandekar A, Mishra DK, Sharma S, Saraogi GK, Gupta U, Gupta G. 3D printing technology: a new milestone in the development of pharmaceuticals. Curr Pharm Des. 2019;25(9):937-45. https://doi.org/10.21 74/1381612825666190507115504

14. Mandrycky C, Wang Z, Kim K, Kim D-H. 3D bioprinting for engineering complex tissues. Biotechnol Adv. 2016;34(4):422-34. https://doi.org/10.1016/ j.biotechadv.2015.12.011

15. Paxton NC, Powell SK, Woodruff MA. Biofabrication. Tech Orthop. 2016;31(3): 190-203. https://doi.org/10.1097/bto.0000000000000184.

16. Gungor-Ozkerim PS, Inci I, Zhang YS, Khademhosseini A, Dokmeci MR. Bioinks for 3D bioprinting: an overview. Biomater Sci. 2018;6(5):915-46. https://doi.org/10.1039/c7bm00765e.

17. Martelli N, Serrano C, van den Brink H, Pineau J, Prognon P, Borget I, et al. Advantages and disadvantages of 3-dimensional printing in surgery: a 
systematic review. Surgery. 2016;159(6):1485-500. https://doi.org/10.1016/j. surg.2015.12.017.

18. Fan D, Li Y, Wang X, Zhu T, Wang Q, Cai H, et al. Progressive 3D printing technology and its application in medical materials. Front Pharmacol. 2020; 11. https://doi.org/10.3389/fphar.2020.00122.

19. Ballard DH, Mills P, Duszak R Jr, Weisman JA, Rybicki FJ, Woodard PK. Medical 3D printing cost-savings in orthopedic and maxillofacial surgery: cost analysis of operating room time saved with 3D printed anatomic models and surgical guides. Acad Radiol. 2019;27(8):1103-13. https://doi. org/10.1016/j.acra.2019.08.011.

20. SME Annual Report 2018. Medical Additive Manufacturing 3D Printing. https://www.sme.org/globalassets/sme.org/media/white-papers-a ndreports/2018-sme-medical-am3dp-annual-report.pdf.

21. Mayo Clinic. Anatomical 3D Printing Lab 2020. https://www.mayoclinic.org/ es-es/departments-centers/anatomic-modelinglaboratories/overview/ovc-2 0473121.

22. L'Institut d'Investigació i Innovació Parc Taulí. 3D Lab 2020. http://www.tauli. cat/es/institut/plataformes-i-serveis/laboratori-3d/.

23. Hospital for Special Surgery 2019. HSS 3D Printing Lab for Complex, Personalized Ortho Implants. https://news.hss.edu/hss-opening-3d-printinglab-for-complex-personalized-ortho-implants/.

24. Liu W, Shao Z, Rai S, Hu B, Wu Q, Hu H, et al. Three-dimensional-printed intercalary prosthesis for the reconstruction of large bone defect after jointpreserving tumor resection. J Surg Oncol. 2020;121(3):570-7. https://doi. org/10.1002/jso.25826.

25. Angelini A, Trovarelli G, Berizzi A, Pala E, Breda A, Ruggieri P. Threedimension-printed custom-made prosthetic reconstructions: from revision surgery to oncologic reconstructions. Int Orthop. 2018;43(1):123-32. https:// doi.org/10.1007/s00264-018-4232-0.

26. Fang C, Cai H, Kuong E, Chui E, Siu YC, Ji T, et al. Surgical applications of three-dimensional printing in the pelvis and acetabulum: from models and tools to implants. Unfallchirurg. 2019;122(4):278-85. https://doi.org/10.1007/ s00113-019-0626-8.

27. Angelini A, Kotrych D, Trovarelli G, Szafrański A, Bohatyrewicz A, Ruggieri P. Analysis of principles inspiring design of three-dimensional-printed custommade prostheses in two referral centres. Int Orthop. 2020;44(5):829-37. https://doi.org/10.1007/s00264-020-04523-y.

28. Dhawan A, Kennedy PM, Rizk EB, Ozbolat IT. Three-dimensional bioprinting for bone and cartilage restoration in orthopaedic surgery. J Am Acad Orthop Surg. 2019;27(5):e215-26. https://doi.org/10.5435/jaaos-d-17-00632.

29. Midha S, Dalela M, Sybil D, Patra P, Mohanty S. Advances in threedimensional bioprinting of bone: progress and challenges. J Tissue Eng Regen Med. 2019. https://doi.org/10.1002/term.2847.

30. Shahabipour F, Ashammakhi N, Oskuee RK, Bonakdar S, Hoffman T, Shokrgozar MA, et al. Key components of engineering vascularized 3dimensional bioprinted bone constructs. Transl Res. 2020;216:57-76. https:// doi.org/10.1016/j.trsl.2019.08.010,

31. Christensen A, Rybicki FJ. Maintaining safety and efficacy for 3D printing in medicine. 3D Printing in. Medicine. 2017;3(1):1. https://doi.org/10.1186/s412 05-016-0009-5.

32. Green N, Glatt V, Tetsworth K, Wilson LJ, Grant CA. A practical quide to image processing in the creation of 3D models for orthopedics. Tech Orthop. 2016;31(3):153-63. https://doi.org/10.1097/bto.0000000000000181.

33. Pascau J, Moreta-Martinez R, Garcia-Mato D, Garcia-Sevilla M, Perez-Mananes $\mathrm{R}$, Calvo-Haro J. Augmented reality in computer assisted interventions based on patient-specific 3D printed reference. Healthc Technol Lett. 2018; 5(5):162-6. https://doi.org/10.1049/htl.2018.5072.

34. Moreta-Martinez R, García-Mato D, García-Sevilla M, Pérez-Mañanes R, CalvoHaro JA, Pascau J. Combining augmented reality and 3D printing to display patient models on a smartphone. J Vis Exp. 2020;(155):e60618. https://doi. org/10.3791/60618.

35. Instituto tecnológico de Canarias. Ingeniería biomédica. Hitos. Primeros implantes óseos a medida en España. 2013. https://www.itccanarias.org/ web/es/areas/ingenieria-biomedica

36. Ahlfeld T, Cubo-Mateo N, Cometta S, Guduric V, Vater C, Bernhardt A, et al. A novel plasma-based bioink stimulates cell proliferation and differentiation in bioprinted, mineralized constructs. CS Appl Mater Interfaces. 2020;12(11): 12557-72. https://doi.org/10.1021/acsami.0c00710.

37. Cubo N, Garcia M, Del Cañizo JF, Velasco D, Jorcano JL. 3D bioprinting of functional human skin: production and in vivo analysis. Biofabrication. 2016; 9(1):015006. https://doi.org/10.1088/1758-5090/9/1/015006.
38. Wu C, Deng J, Li T, Tan L, Yuan D. Percutaneous pedicle screw placement aided by a new drill guide template combined with fluoroscopy: an accuracy study. Orthop Surg. 2020;12(2):471-9. https://doi.org/10.1111/os.12642.

39. Gregory TM, Alkhaili J, Silvera J, Vitis B, Chaves C, Gregory J. 3D printing technology for the classification of complex distal humerus fractures. Ann Joint. 2018;3:96. https://doi.org/10.21037/aoj.2018.10.05.

40. Yang L, Shang X-W, Fan J-N, He Z-X, Wang J-J, Liu M, et al. Application of $3 \mathrm{D}$ printing in the surgical planning of trimalleolar fracture and doctorpatient communication. Biomed Res Int. 2016;2016:1-5. https://doi.org/10.11 $55 / 2016 / 2482086$

41. Mitsouras D, Liacouras P, Imanzadeh A, Giannopoulos AA, Cai T, Kumamaru KK, et al. Medical 3D printing for the radiologist. Radiographics. 2015;35(7): 1965-88. https://doi.org/10.1148/rg.2015140320.

42. Mitsouras D, Liacouras PC, Wake N, Rybicki FJ. RadioGraphics update: medical 3D printing for the radiologist. Radiographics. 2020;40(4):E21-3. https://doi.org/10.1148/rg.2020190217.

43. Pérez-Mañanes R, Calvo-Haro J, Arnal-Burró J, Chana-Rodríquez F, Sanz-Ruiz P, Vaquero-Martín J. Nuestra experiencia con impresión 3D doméstica en Cirugía Ortopédica y Traumatología. Hazlo tú mismo. Revista Latinoamericana de Cirugía Ortopédica. 2016;1(2):47-53. https://doi.org/10.1 016/.j.rlaot.2016.06.004.

44. Pérez-Mañanes R, Arnal J, et al. 3D surgical printing cutting guides for openwedge high tibial osteotomy: DIY. J Knee Surg. 2016;29(08):690-5. https:// doi.org/10.1055/s-0036-1572412 https://www.thieme-connect.com/ products/ejournals/abstract/10.1055/s-0036-1572412.

45. Arnal J, Pérez-Mañanes R, et al. Three dimensional-printed patient-specific cutting guides for femoral variation osteotomy: do it yourself. Knee. 2017; 24(6):1359-68. https://doi.org/10.1016/j.knee.2017.04.016 https://www.ncbi. nlm.nih.gov/pubmed/28978460.

46. Chana F, Pérez-Mañanes $R$, et al. 3D surgical printing and pre contoured plates for acetabular fractures. Injury. 2016. https://doi.org/10.1016/j.injury.2 016.08.027 https://www.ncbi.nlm.nih.gov/pubmed/27599393.

47. García-Vázquez V, Pérez-Mañanes R, Calvo JA, García-Mato D, CuervoDehesa M, Desco M, et al. Desktop 3D printing in medicine to improve surgical navigation in acral tumors. Int J CARS. 2016;11(Suppl 1):S262-3.

48. García-Vázquez V, Rodríguez-Lozano G, Pérez-Mañanes R, Calvo JA, MoretaMartínez R, Asencio JM, et al. Surgical navigation and 3D printing in hemipelvic osteotomy. Int J CARS. 2017;12(Suppl 1):S106-7.

49. Chepelev L, Wake N, Ryan J, Althobaity W, Gupta A, et al. Radiological Society of North America (RSNA) 3D printing Special Interest Group (SIG): guidelines for medical 3D printing and appropriateness for clinical scenarios. 3D Printing in. Medicine. 2018;4(1):11. https://doi.org/10.1186/s412 05-018-0030-y.

50. Morgan C, Khatri C, Hanna SA, Ashrafian H, Sarraf KM. Use of threedimensional printing in preoperative planning in orthopaedic trauma surgery: a systematic review and meta-analysis. World J Orthop. 2019;11(1): 57-67. https://doi.org/10.5312/wjo.v11.11.57.

51. Comunidad de Madrid. Servicios e información. El Hospital Gregorio Marañón salva a un hombre con rotura de aorta gracias a la impresión 3D. 2019. https://www.comunidad.madrid/noticias/2019/09/25/hospitalgregorio-maranon-salva-hombre-rotura-aorta-gracias-impresion-3d.

52. Park L, Price-Williams S, Jalali A, Pirzada K. Increasing access to medical training with three-dimensional printing: creation of an endotracheal intubation model. JMIR Med Educ. 2019;5(1):e12626. https://doi.org/10.21 96/12626.

53. Gallagher PO, Bishop N, Dubrowski A. Investigating the perceived efficacy of a silicone suturing task trainer using input from novice medical trainees. Cureus. 2020. https://doi.org/10.7759/cureus.6612.

54. Parkhomenko E, Yoon R, Okhunov Z, Patel RM, Dolan B, Kaler K, et al. Multiinstitutional evaluation of producing and testing a novel 3D-printed laparoscopic trainer. Urology. 2019;124:297-301. https://doi.org/10.1016/j. urology.2018.06.034.

55. Torres I, De Luccia N. Artificial vascular models for endovascular training (3D printing). Innov Surg Sci. 2018:3(3):225-34. https://doi.org/10.1515/iss-20180020.

56. Zhu J, Wen G, Tang C, Zhong C, Yang J, Ma C. A practical 3D-printed model for training of endoscopic and exoscopic intracerebral hematoma surgery with a tubular retractor. J Neurol Surg A Cent Eur Neurosurg. 2020;81(05): 404-11. https://doi.org/10.1055/s-0039-1697023.

57. Hussein N, Lim A, Honjo O, Haller C, Coles JG, Van Arsdell G, et al. Development and validation of a procedure-specific assessment tool for 
hands-on surgical training in congenital heart surgery. J Thorac Cardiovasc Surg. 2019;160(1):229-240.e1. https://doi.org/10.1016/j.jtcvs.2019.11.130.

58. Reighard CL, Green K, Powell AR, Rooney DM, Zopf DA. Development of a high fidelity subglottic stenosis simulator for laryngotracheal reconstruction rehearsal using 3D printing. Int J Pediatr Otorhinolaryngol. 2019;124:134-8. https://doi.org/10.1016/jijporl.2019.05.027.

59. McMenamin PG, Quayle MR, McHenry CR, Adams JW. The production of anatomical teaching resources using three-dimensional (3D) printing technology. Anat Sci Educ. 2014;7(6):479-86. https://doi.org/10.1002/ase.1475.

60. Lim KHA, Loo ZY, Goldie SJ, Adams JW, McMenamin PG. Use of 3D printed models in medical education: a randomized control trial comparing 3D prints versus cadaveric materials for learning external cardiac anatomy. Anat Sci Educ. 2015;9(3):213-21. https://doi.org/10.1002/ase.1573.

61. Wilk R, Likus W, Hudecki A, Syguła M, Różycka-Nechoritis A, Nechoritis K. What would you like to print? Students' opinions on the use of 3D printing technology in medicine. PLoS One. 2020;15(4):e0230851. https://doi.org/1 0.1371/journal.pone.0230851

62. Woo S-H, Sung M-J, Park K-S, Yoon T-R. Three-dimensional-printing technology in hip and pelvic surgery: current landscape. Hip Pelvis. 2020; 32(1):1-10. https://doi.org/10.5371/hp.2020.32.1.1.

63. Xia R, Zhai Z, Chang Y, Li H. Clinical applications of 3-dimensional printing technology in hip joint. Orthop Surg. 2019;11(4):533-44. https://doi.org/1 $0.1111 /$ os. 12468

64. Henckel J, Holme TJ, Radford W, Skinner JA, Hart AJ. 3D-printed patientspecific guides for hip arthroplasty. J Am Acad Orthop Surg. 2018;26(16): e342-8. https://doi.org/10.5435/jaaos-d-16-00719.

65. Hurst EJ. 3D printing in healthcare: emerging applications. J Hosp Librariansh. 2016;16(3):255-67. https://doi.org/10.1080/15323269.2016.11 88042.

66. Otero JJ, Vijverman A, Mommaerts MY. Use of fused deposit modeling for additive manufacturing in hospital facilities: European certification directives. J Cranio-Maxillofac Surg. 2017;45(9):1542-6. https://doi.org/10.1016/j.jcms.2 017.06.018.

67. Morrison RJ, Kashlan KN, Flanangan CL, Wright JK, Green GE, Hollister SJ, et al. Regulatory considerations in the design and manufacturing of implantable 3D-printed medical devices. Clin Transl Sci. 2015;8(5):594-600. https://doi.org/10.1111/cts.12315.

68. European Parliament, Council of the European Union. Regulation (EU) 2017/ 745 of the European Parliament and of the Council of 5 April 2017 on medical devices, amending Directive 2001/83/EC, Regulation (EC) no 178/ 2002 and Regulation (EC) no 1223/2009 and repealing Council Directives 90/385/EEC and 93/42/EEC. https://www.emergogroup.com/sites/default/ files/europe-medical-devices-regulation.pdf. Accessed 21 Feb 2019.

\section{Publisher's Note}

Springer Nature remains neutral with regard to jurisdictional claims in published maps and institutional affiliations.

Ready to submit your research? Choose BMC and benefit from:

- fast, convenient online submission

- thorough peer review by experienced researchers in your field

- rapid publication on acceptance

- support for research data, including large and complex data types

- gold Open Access which fosters wider collaboration and increased citations

- maximum visibility for your research: over $100 \mathrm{M}$ website views per year

At $\mathrm{BMC}$, research is always in progress.

Learn more biomedcentral.com/submissions 